THE EFFECT OF COMPETENCE AND COMPENSATION TO MOTIVATION OF EMPLOYEES AND ITS IMPACT ON EMPLOYEE PERFORMANCE IN THE PERSONNEL AND TRAINING BOARD OF KARAWANG REGENCY

\title{
THE EFFECT OF COMPETENCE AND COMPENSATION TO MOTIVATION OF EMPLOYEES AND ITS IMPACT ON EMPLOYEE PERFORMANCE IN THE PERSONNEL AND TRAINING BOARD OF KARAWANG REGENCY
}

\author{
Yanti Dwi Indarti ${ }^{1 *}$ \\ ${ }^{1}$ Universitas Singaperbangsa Karawang, Karawang, Indonesia
}

\begin{abstract}
The performance level of the Personnel and Training Board of Karawang Regency in 2016 is less than 100\%. This is thought to be influenced by various factors such as Competence, Compensation and Work Motivation. Because of interest in the problem, this study has a purpose to find out, analyze and explain about the influence of Competence and Compensation for Work Motivation and its Impact on Employee Performance at the Personnel Staffing and Training of Karawang regency.

To analyze the problem, we had 58 respondents answer through the Nonprobability Sampling technique with the saturated sampling method. The data collection technique used the survey method with a questionnaire tool. Data analysis was done by validity test, reliability test, descriptive analysis and verified analysis with a multiple linear regression. Data processing used the SPSS Version 17.00 software application

The results of the research conducted at the Personnel and Training Board Karawang regency shows that 1) Employee competence has a very good criteria, Compensation has a good criterion, Motivation Work and Employee Performance has a very high criteria; 2) Competence with Compensation has a positive and significant correlation at a low correlation level with a correlation coefficient of 0.329 ; 3) Competence has a positive and significant effect of $11 \%$ to Work Motivation with a path coefficient of 0,255 and Compensation has a positive and significant effect of $33.8 \%$ to Work Motivation with a path coefficient of 0.541 ; 4) Competence and Compensation effect simultaneously positive and significant equal to 44,8\% to Work Motivation; 5) Competence has a positive and significant effect of $14.7 \%$ to Employee Performance with a path coefficient of 0.298 and Compensation has a positive and significant effect of $41 \%$ to Employee Performance with a path coefficient of 0.593; 6) Competence and Compensation effect simultaneously positive and significant equal to $55,7 \%$ to Employee Performance; 7) Work Motivation has a positive and significant effect of $66.4 \%$ on Employee Performance with a path coefficient of 0.815; 8) Competence Through Work Motivation has a positive and significant effect of $29.8 \%$ to Employee Performance and Compensation Through Work Motivation has a positive and significant effect of $59.3 \%$ to Employee Performance; 9) Competence and Compensation Through Work Motivation influence simultaneously positive and significant equal to $89,1 \%$ to Employee Performance.

The influence of other variables are not examined outside the Competence and Compensation through the Job Motivation to Employee Performance of 10,9\%, so there needs to be further research on other variables to obtain comprehensive information in order to improve the Performance of Employees in the Personnel Board and Training Board Karawang regency.
\end{abstract}

Keywords: Competence, Compensation, Employee Performance, Work Motivation.

* Corresponding author. Email address: yantidwibangrier@gmail.com 


\section{INTRODUCTION}

Performance is a result that every organization desires to reach. For reaching a good performance, an organization needs employees that have high work potential for anticipating environmental opportunities and challenges which are more competitive for reaching the organization's goals, so human resource management needs to be directed to be the thinker and determinant of the organization's way sustainably. "Performance is an implementation from plans arranged by the organization, Performance implementation is implemented by human resources which have the ability, competence, motivation, and interest" (Wibowo, 2009;4). Competence influences employee performance, if an employee has a high competence such as knowledge, skill, ability, and attitude that is corresponding with the carried position he or she will be motivated to work efficiently, effectively, and productively. "Competence is the behavior dimension which is behind competent performance. Often named behavior competence because it is meant for explaining how people behave when they perform their roles well" (Armstrong and Baron, 1998:298 in Wibowo, 2009:326). Motivation is a factor in competence which is able to change. By providing motivation, appreciation to employee performance is able to have a positive influence to employee motivation. If directors are able to encourage personal motivations of an employee, then synchronize with the organization's needs, they will often find an assignment increase in a number of competence which influence performance. "...motivation represents psychological processes, which causes the emergence, direction, and occurrence of the persistence of volunteer activities which are directed in the direction of certain goals" (Mitchell, 1982:81 in J.Winardi, 2011:1). Other than competence, financial compensation is one of the aspects which influence employee performance. In fulfilling employee work satisfaction, providing financial compensation to employees need to be paid attention. Providing proper compensation equally for employees will create a pleasant work environment and able to cause a high work motivation for employees. "In providing and deciding for remuneration compensation levels for employees, there are matters to be considered. The consideration of providing this remuneration compensation has to be based on a logical reason, so it will be able to create satisfaction for employees." (Nasution, 1994:160 in Kadarisman,2014:23).

Based on the phenomenon in the Personnel and Training Board Karawang regency that the cause of the performance achievement level which is not yet optimal is caused by, among others, the availability of employees which is not equal to the number of employees in the whole Karawang Regency Government which need to be served, the low employee competence and not yet corresponding with the placement in their positions, there are still employees which have not yet mastered technology, compensation which is not yet corresponding from the amount and the proportion between position gaps, and employee work motivation which is not yet optimal. So the writer desires to research "The Effect Of Competence And Compensation To Motivation Of Employees And Its Impact On Employee Performance In The Personnel And Training Board Of Karawang Regency". 
THE EFFECT OF COMPETENCE AND COMPENSATION TO MOTIVATION OF EMPLOYEES AND ITS IMPACT ON EMPLOYEE PERFORMANCE IN THE PERSONNEL AND TRAINING BOARD OF KARAWANG REGENCY

\section{THEORETICAL BASE AND HYPOTHESIS DEVELOPMENT}

\section{Competence}

"Competence is a behavior dimension behind the competent performance. Often named behavior competence because it is meant for explaining how people behave when they perform their roles well" (Armstrong and Baron, 1998:298 cited by Wibowo, 2010:326). "Competence is a basic characteristic of individual behavior which is related with the effective mold criteria and or excellent performance in work or situations" (Lyle Spencer and Signe Spencer, 1993:9 in Sudarmanto, 2015:46). "Competence clusters and dimensions are divided through dimensions that prioritize achievement and action, aid, and serve other people, the ability to influence and create impact, managerial ability, cognition ability, personal effectiveness ability" (Lyle Spencer and Signe Spencer, 1993:9 in Sudarmanto, 2015: 70-71).

\section{Compensation}

"Appreciation (reward) has the meaning of appreciations/rewards which organizations give to their members, which are financial material, nonfinancial material, or psychological or non-material. Forms of appreciation are in the forms of: basic salary/basic wage, variable salary, incentives, achievement service money (bonus), opportunities of career/promotion, holiday, pension" Sudarmanto, 2015:192). "Compensation is what an employee/worker obtains as a reward of the work provided" (Kadarisman, 2014:1)."Compensation is able to be measured through dimensions which are results and goals which are expected from appreciation, individual criteria and measure which is given appreciation, characteristic or form of appreciation, equality level of the appreciation system and appreciation time range" (Sudarmanto, 2015:200-201 and Kardisman, 2014:23-24).

\section{Work Motivation}

"Motivation refers to the strength from the inside and the outside of a person which awakens sustains the commitment for an action" (David Boddy, 2008:486). Motivation is a psychological process which awakens and directs behavior in reaching goals or goal-directed behavior" (Robert Kreitner and Angelo Kinicki, 2003 in Wibowo, 2010:378). "According to the Motivation Theory related with performance, that motivation is able to be obtained through Needs, Job Design, Satisfaction, Equity, Expectation, and Goal Setting" (Kreitner and Angelo Kinicki, 2003:2010 in Wibowo, 2010:391-399).

\section{Performance}

"Performance is about implementing work and the results reached from that work, about what is done and how it is done. Performance is the work result which has a strong relation with strategic goals and the organization, consumer satisfaction, and provide contribution to the economy" (Armstrong and Baron, 1998:150 in Wibowo, 2017:70). "Referring to the definition as a result which states that performance is a produced record of results of certain work functions or activities for a certain time period" (Bernardin, 2001:143 in Sudarmanto, 2015:8). "Performance or the dimensions to measure performance are Quality, quantity, timeliness, cost-effectiveness, need for supervision and interpersonal impact" (Bernardin, 2001 in Sudarmanto 2015:12). 


\section{FRAMEWORK}

Competence Dimension (Spencer, 1993 in Sudarmanto, 2015:70-71) which are (1) Achievement and Action oriented with a passionate indicator for achievement and for reaching work targets, attention to work quality and detail, proactive and initiative, searching Information; (2) Assisting and serving other persons with the empathy indicator, customer oriented; (3) Ability to influence and create impact with the indicator of a wide impact and influence, organizational awareness, building job relations; (4) Managerial ability with the indicator to develop other persons, ability to direct/provide orders, group cooperation, leading groups; (5) Cognition ability with the indicators of analytical thinking, conceptual thinking, technical/professional/managerial skills; (6) personal effectiveness ability with indicators of self-control, confidence, flexibility, organizational commitment.

Compensation Dimension (Sudarmanto, 2015:200-201 and Kadarisman, 2014:23-24) which are (1) Results and goals expected from appreciation are equalized with the indicator of corresponding levels of appreciation with the employee expectations and needs, appreciation level motivation to employee spirit or passion of the job, appreciation system motivation level to employee desire to still work in the organization environment, appreciation system benefit level to work satisfaction; (2) Criteria and measure of individuals which are given appreciation with the indicators of level of appreciation corresponding with performance, level of appreciation corresponding with responsibility, level of appreciation corresponding with rank and position, level of appreciation corresponding with job load, level of appreciation corresponding with education, level of appreciation corresponding with job length; (3) Characteristic or form of appreciation with indicators of appreciation variation, appreciation number/amount; (4) appreciation system equity level with the indicators of how far the appreciation level fulfills the feeling of equity to employees, how far the appreciation level fulfills the feeling of equity from the organization ability point of view; (5) appreciation time range with the indicator of how long the appreciation is provided compared with activities in work.

Motivation Dimension (Kreitner and Angelo Kinicki, 2003:2010 in Wibowo, 2010:391-399) which are (1) Needs with the indicators of the need for achievement, the need for affiliation, the need for power; (2) Job Design with the indicators of scientific management, job enlargement, job rotation, job enrichment; (3) Satisfaction with the indicators of need fulfillment, discrepancies, value attainment, equity, genetic component; (4) Equity with the indicators of equity in social exchange, equity in providing and accepting relations; (5) Expectation with the indicators of expectancy (certain effort levels will be followed by certain performance levels), instrumentally (certain results are dependent on specific performance levels), valence (positive or negative values which persons place in results; (6) Goal Setting with the indicators of goals direct attention (goals focus on one matter which is relevant and important), goals regulate effort (effort levels are implemented proportionally with goal difficulty) goals increase persistence (persistence in effort for the time period extension), goals accelerate strategies and action plans (goals encourage developing strategies and action plans). 
THE EFFECT OF COMPETENCE AND COMPENSATION TO MOTIVATION OF EMPLOYEES AND ITS IMPACT ON EMPLOYEE PERFORMANCE IN THE PERSONNEL AND TRAINING BOARD OF KARAWANG REGENCY

Performance Dimension (Bernardin, 2001 in Sudarmanto, 2015:12) which are (1) Quality with process indicators or results nearing perfect/fulfills quality standards, ease of procedure/steps of service, service requirements corresponding with the service type; (2) Quantity with the indicator of number or quantity of job results corresponding with the target; (3) Timeliness with the indicator of punctuality in finishing activities or producing products, timeliness accuracy in every change of the good/service until at the consumer, certainty of service schedule, low level of absence or tardiness of service personnel; (4) Cost-Effectiveness with the indicators of waste reduction in using organizational resources (persons, money, material, technology), using organizational resources which are corresponding with the service type and of good quality, fairness of service costs, certainty of service costs; (5) Need for supervision with the indicators of service personnel clarity, service personnel discipline, service personnel responsibility, service personnel honesty; (6) Interpersonal Impact with the indicators of cooperation with other persons (with employees and leaders) in work, the ability to influence coworker behavior, the ability to influence consumer behavior.

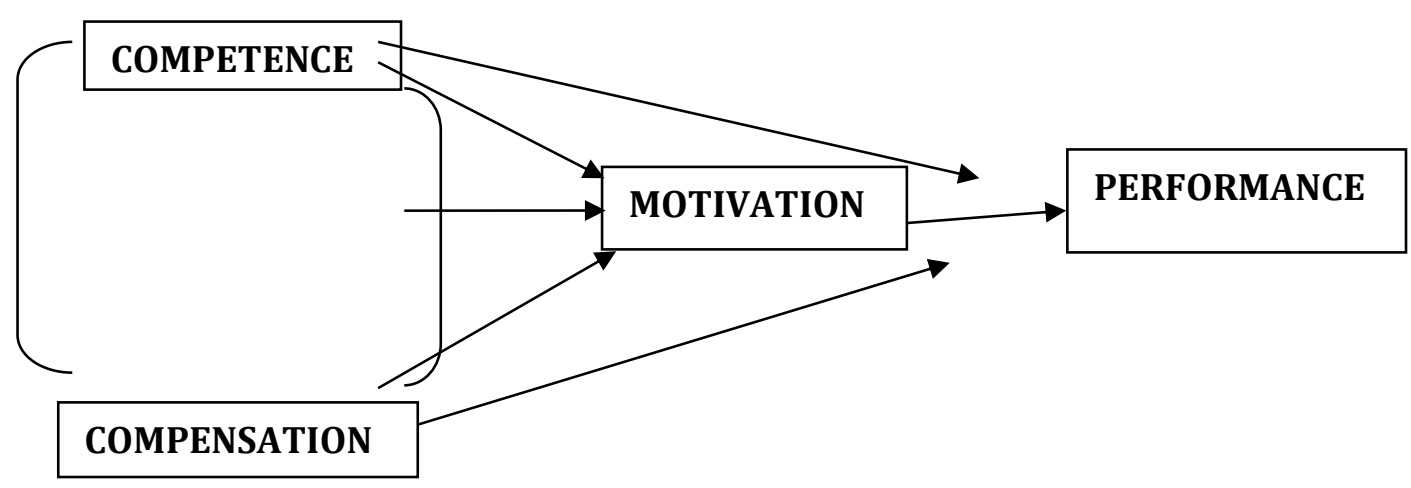

Figure 1 Research Paradigm

Source: Processed based on source for research needs

\section{Research Hypothesis}

The hypotheses in this research are:

1) There is a correlation between Competence and Compensation;

2) There is an influence of Competence and Compensation partially to Work Motivation;

3) There is an influence of Competence and Compensation simultaneously to Work Motivation;

4) There is an influence of Competence and Compensation partially to Employee Performance;

5) There is an influence of Competence and Compensation simultaneously to Employee Performance;

6) There is an influence of Work Motivation to Employee Performance;

7) There is an influence of Competence and Compensation partially through Work Motivation to Employee Performance;

8) There is an influence of Competence and Compensation simultaneously through Work Motivation to Employee Performance. 


\section{RESEARCH METHOD}

The research object is the Personnel and Training Board of Karawang Regency. The method used is the explanatory survey method, which is analyzing the influence that occurs between the competition variable $\left(\mathrm{X}_{1}\right)$, compensation variable $\left(\mathrm{X}_{2}\right)$ and Work Motivation (Y) with employee performance $(\mathrm{Z})$. The population in this research are the employees of the Personnel and Training Board of Karawang Regency with the sample determination technique by saturated sampling so all employees which total at 58 persons are created as respondents.

Data gathering is implemented by distributing questionnaires which consists of 4 variables, which are the Competence Variable, Compensation Variable, Work Motivation Variable, and Performance Variable with questions of each variable as many as 21 question items. The scale used is the likert scale with answer ranges of 1 to 5 ( $1=$ strongly disagree, $2=$ disagree $3=$ less agree; $4=$ agree $5=$ strongly agree).

The data analysis method which will be used is this research consists of the Classic Assumption Test and Hypothesis Test with a path analysis. The data analysis technique uses the aid of SPSS 17.0 software.

\section{CLASSIC ASSUMPTION TEST Data Validity Test}

The validity of a data is related with the precision degree between field data with data reported by the researcher. For obtaining valid data in the quantitative method an instrument validity test is needed. Instrument validity illustrates instrument levels which are able to measure what is measured (Suharsimi Arikunto, 2003:219). The SPSS test technique is often used for validity tests by using the Bivariate Pearson (Pearson Product Moment) and Corrected Item-Total Correlation. The $r$ count value is matched with the $r$ table product moment in the 5\% significance level. If the $\mathrm{r}$ count is larger than the 5\% $\mathrm{r}$ table, the item is valid.

From the variable validity tests of the Competence variable $\left(\mathrm{X}_{1}\right)$, Compensation variable $\left(\mathrm{X}_{2}\right)$, Motivation variable $(\mathrm{Y})$, and Performance variable $(\mathrm{Z})$ it is obtained that $\mathbf{2 1}$ question items are wholly valid, because $\mathrm{r}$ count is larger than $r$ table.

\section{Data Reliability Test}

Reliability is related with the consistence degree and data stability or findings. A data is said to be reliable if investigated by different researchers, the data is the same, likewise if implemented in a different time, the same data is obtained, of course it is related with the same sample. By using SPSS, the Reliability Test notes the Reliability Statistics table. Data is reliable if the Cronbach Alpha result is $>0.60$. Meaning answer consistence $>60 \%$.

From the reliability test results of the Competence variable $\left(\mathrm{X}_{1}\right)$, Compensation variable $\left(\mathrm{X}_{2}\right)$, Motivation variable $(\mathrm{Y})$, and Performance variable (Z) it is obtained that the four variables are wholly reliable because the Cronbach Alpha value is larger than 0.060.

\section{Data Normality Test}

The normality test is a test of the normality of the distribution of competence data $\left(\mathrm{X}_{1}\right)$, compensation data $\left(\mathrm{X}_{2}\right)$, work motivation data $(\mathrm{Y})$, and 
THE EFFECT OF COMPETENCE AND COMPENSATION TO MOTIVATION OF EMPLOYEES AND ITS IMPACT ON EMPLOYEE PERFORMANCE IN THE PERSONNEL AND TRAINING BOARD OF KARAWANG REGENCY

employee performance (Z). This matter is implemented by using the kolmogorov-smirnov test using spss. With the criteria if the significance number $(\mathrm{sig})<0.05$ data is not normally distributed, and a significance number (sig) of $>0.05$ data is normally distributed.

The normality test result is seen in the Asympt.Sig. (2-tailed) shows the significance level is larger than $\alpha=0.05$ which is $0.716>0.05$ which means that data is distributed NORMALLY. For the Z Kolmogorov-Smirnov value. The Unstandardized Residual $\mathrm{Z}$ variable value $=0.697$. If that $\mathrm{Z}$ value is compared with 1.97 (for the significance level of 0.05 ), so $0.697<1.97$, so data is stated to be NORMALLY distributed.

\section{Data Transformation}

Data transformation is the implemented effort with the purpose of changing the real data measurement into another form so data is able to fulfill assumptions which underlies statistical analysis, so data is ready to be analyzed. Considering the analysis used is the path analysis, it is required that the measurement scale used is at least the interval scale. Because data obtained from the research instrument is ordinal data, so it is able to be analyzed for the relation, the data has to be improved (transformed) from ordinal to interval by using the method of successive interval (MSI).

\section{ANALYSIS DESIGN AND HYPOTHESIS TEST DESCRIPTIVE ANALYSIS}

The scale range with samples as many as 58 employees with using an equation as the following:

where :

$$
R S=\frac{n(m-1)}{m}=\frac{58(5-1)}{5}=46,4
$$

$$
\begin{array}{lll}
\mathrm{RS} & : \text { Scale Range } \\
\mathrm{n} & : \text { Total Samples } \\
\mathrm{m} & : \text { Total Alternative Answers (Score) }
\end{array}
$$

Lowest scale $=$ Lowest score value $\mathrm{x}$ total samples $=1 \mathrm{x} 58=58$

Highest scale $=$ Highest score value $\mathrm{x}$ total samples $=58 \times 5=290$

Table 1 Scale Range

\begin{tabular}{c|c|c}
\hline Score Scale & Scale Range & Criteria \\
\hline 1 & $58-104.4$ & Not Very Good \\
\hline 2 & $104.5-150.8$ & Not Good \\
\hline 3 & $150.9-197.2$ & Poor \\
\hline 4 & $197,3-243.6$ & Good \\
\hline 5 & $243.7-290$ & Very Good \\
\hline
\end{tabular}

Source: Processed based on source for research needs 


\begin{tabular}{|l|l|l|l|l|}
$\begin{array}{l}\text { Not Very } \\
\text { Good }\end{array}$ & Not Good & Poor & Good & Very Good \\
\hline 58 & 104.4 & 150.8 & 197.2 & 243.6
\end{tabular}

Figure 2 Bar Scale

Source: Processed based on source for research needs

\section{VERIFIED ANALYSIS}

\section{Correlation Analysis}

Table 2 R Correlation Interpretation

\begin{tabular}{c|c}
\hline Coefficient Interval & Correlation \\
\hline $0.00-0.199$ & Very Low \\
\hline $0.20-0.399$ & Low \\
\hline $0.40-0.599$ & Average \\
\hline $0.60-0.799$ & Strong \\
\hline $0.80-1.000$ & Very Strong \\
\hline \multicolumn{2}{c}{ Source: Sugiyono (2014:184) }
\end{tabular}

For knowing the correlation significance, the Significance is able to be observed, if the Sig value $<0.05$ there is a significant correlation $\left(\mathrm{H}_{1}\right.$ accepted $)$, If the $\mathrm{Sig}$ value $>0.05$ there is no significant correlation $\left(\mathrm{H}_{0}\right.$ accepted $)$.

\section{Path Analysis}

The path analysis is an analysis that the researcher uses for knowing the presence or absence of influence between the Competence $\left(\mathrm{X}_{1}\right)$ and Compensation $\left(\mathrm{X}_{2}\right)$ variables to Work Motivation $(\mathrm{Y})$ and the impact to Employee Performance (Z).

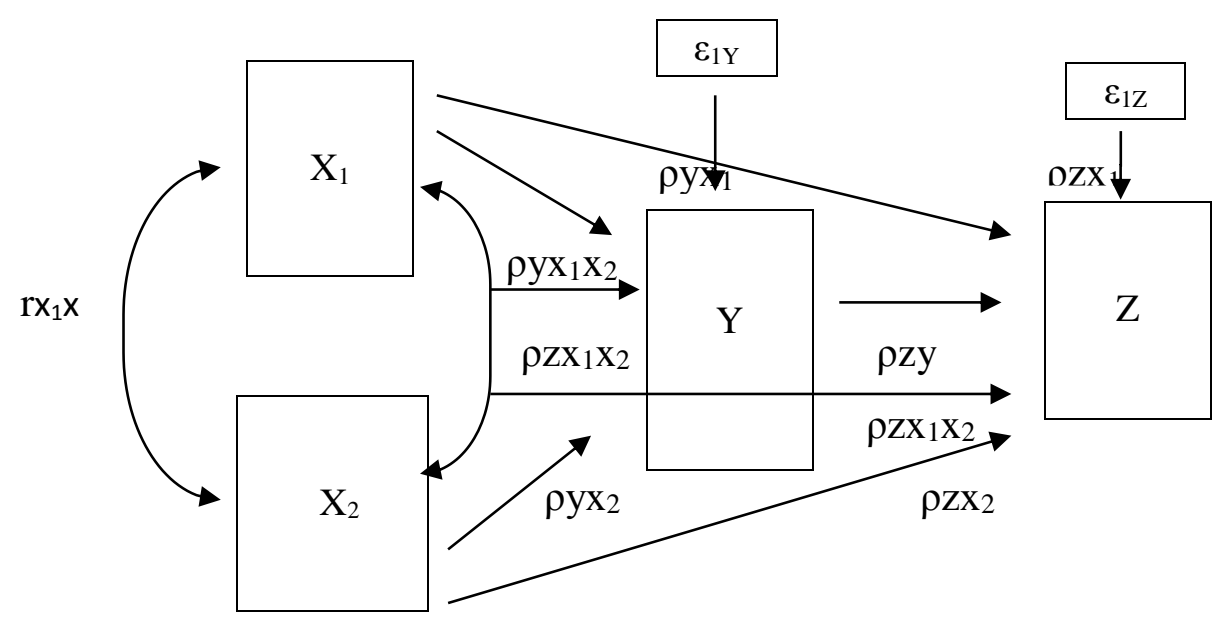


THE EFFECT OF COMPETENCE AND COMPENSATION TO MOTIVATION OF

EMPLOYEES AND ITS IMPACT ON EMPLOYEE PERFORMANCE IN THE PERSONNEL

AND TRAINING BOARD OF KARAWANG REGENCY

Figure 3 Path Analysis

Source: Processed based on source for research needs

Equation :

$$
\begin{aligned}
& Y=\rho \mathrm{yx}_{1} \mathrm{X} 1+\rho \mathrm{yx}_{2} \mathrm{X} 2+\rho \varepsilon_{1} \mathrm{y} \\
& Z=\rho \mathrm{yx}_{1} \mathrm{X} 1+\rho \mathrm{yx}_{2} \mathrm{X} 2+\rho \mathrm{zy} Y+\rho \varepsilon_{1} \mathrm{Z}
\end{aligned}
$$

\begin{tabular}{|c|c|}
\hline $\mathrm{X}_{1}$ & Competence \\
\hline $\mathrm{X}_{2}$ & Compensation \\
\hline Y & Motivation \\
\hline $\mathrm{Z}$ & Performance \\
\hline$\rho \mathrm{yx}_{1}$ & Influencing path coefficient $\mathrm{X}_{1}$ to $\mathrm{Y}$ \\
\hline $\operatorname{\rho yx}_{2}$ & Influencing path coefficient $\mathrm{X}_{2}$ to $\mathrm{Y}$ \\
\hline$\rho \mathrm{yx}_{1} \mathrm{x}_{2}$ & Influencing path coefficient $\mathrm{X}_{1}$ and $\mathrm{X}_{2}$ to $\mathrm{Y}$ \\
\hline$\rho z y$ & Influencing path coefficient $\mathrm{Y}$ to $\mathrm{Z}$ \\
\hline$\rho \mathrm{zX}_{1}$ & Influencing path coefficient $\mathrm{X}_{1}$ to $\mathrm{Z}$ \\
\hline$\rho z_{2}$ & Influencing path coefficient $\mathrm{X}_{2}$ to $\mathrm{Z}$ \\
\hline$\rho \mathrm{zx}_{1} \mathrm{x}_{2}$ & Influencing path coefficient $\mathrm{X}_{1}$ and $\mathrm{X}_{2}$ to $\mathrm{Z}$ \\
\hline$\rho z y x_{1}$ & Influencing path coefficient $\mathrm{X}_{1}$ through $\mathrm{Y}$ to $\mathrm{Z}$ \\
\hline$\rho z y x_{2}$ & Influencing path coefficient $\mathrm{X}_{2}$ through $\mathrm{Y}$ to $\mathrm{Z}$ \\
\hline$\rho z x_{1} x_{2}$ & Influencing path coefficient $\mathrm{X}_{1}$ and $\mathrm{X}_{2}$ through $\mathrm{Y}$ to $\mathrm{Z}$ \\
\hline$\varepsilon_{1}$ & Path coefficient of other variables (Error) \\
\hline
\end{tabular}

where :

\section{Determination Coefficient Analysis}

The $\mathrm{R}^{2}$ ( $\mathrm{R}$ Square) determination coefficient is used for predicting the size of the independent variable contribution influence which are Competence $\left(\mathrm{X}_{1}\right)$ and Compensation $\left(\mathrm{X}_{2}\right)$ to the intervening variable which is Motivation $(\mathrm{Y})$ and the size of the intervening variable influence to the dependent variable which is Performance $(\mathrm{Z})$ with the requirement that the $\mathrm{F}$ test requirement in the regression analysis has a significant value. If the $\mathrm{F}$ test result is not significant, the determination coefficient ( $\mathrm{R}$ Square) is not able to be used to predict influence contributions between those variables.

The $\mathrm{R}^{2}$ determination coefficient value is between 0 (zero) and 1 (one). If the $\mathrm{R}^{2}$ is minus in value (-) it is able to be said that there is no independent variable influence to dependent variables. The smaller the $\mathrm{R}^{2}$ determination coefficient, the weaker the influence of the independent variable to the dependent variable. Contrarily, if the $\mathrm{R}^{2}$ value is closer to 1 the influence will be stronger.

\section{HYPOTHESIS TEST}

1) F test

For testing the significance of independent variable influence to dependent variables simultaneously. If the value of $\mathrm{F}$ count $<\mathrm{F}$ table the influencing independent variable is not significant to the dependent variable simultaneously.

For testing the significance of the independent variable influence to dependent variables partially. If the value of $t$ count $<t$ table the influencing independent variable is not significant to the dependent variable partially. 


\section{RESULTS AND DISCUSSION}

\section{CORRELATION ANALYSIS AND PATH ANALYSIS RESULT}

The path analysis result as a whole with the influence of Competence and Compensation to Motivation and its impact to performance is able to be seen in the following illustration:

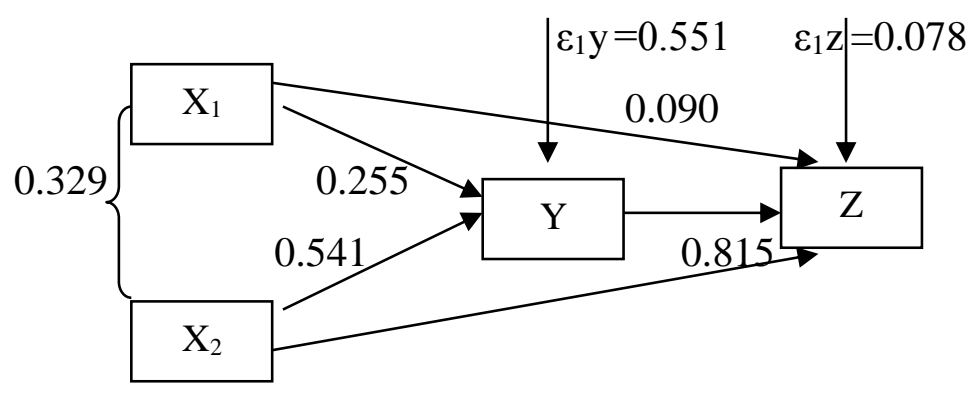

With the equation as the following:

$\mathrm{Z}=0.255 \mathrm{X} 1+0.541 \mathrm{X} 2+0.815 \mathrm{Y}+0.078$

Where:

Z : Performance

Y : Motivation

$\mathrm{X} 1$ : Competence

X2 : Compensation

$\varepsilon_{1 \mathrm{Z}} \quad$ : Path coefficient of other variables as large as 0.078

\section{DESCRIPTIVE DISCUSSION}

\section{Competence Variable Descriptive Discussion}

From the descriptive analysis an average total score of the Competence variable as large as $\mathbf{2 5 7}$ is obtained located in the scale range with the very good criteria, which means respondents already consider that Employee Competence is largely corresponding with the primary task and function of each position.

From the frequency tabulation that the respondent statement to the Competence variable with the largest percentage in the strongly agree criteria which is in the dimension of Achievement Oriented and Action in the Spirit for achievement indicator and to reach the job target, and Attention to work quality and precision. While the largest percentage in the less agree criteria are in the dimensions of cognitive ability in the technical/professional/managerial expertise indicators and personal effectiveness ability in the self-control dimension.

\section{Compensation Variable Descriptive Discussion}

From the descriptive analysis an average total score of the Compensation variable as large as $\mathbf{2 3 9}$ is obtained located in the scale range with the good criteria, which means respondents already consider that the compensation provided by the Personnel and Training Board of Karawang Regency is already corresponding with employee expectations and corresponding with the Personnel and Training Board of Karawang Regency. 
THE EFFECT OF COMPETENCE AND COMPENSATION TO MOTIVATION OF EMPLOYEES AND ITS IMPACT ON EMPLOYEE PERFORMANCE IN THE PERSONNEL AND TRAINING BOARD OF KARAWANG REGENCY

From the frequency tabulation that the respondent statement to the Compensation variable with the largest percentage in the strongly agree criteria which is in the dimension of Results and goals which is expected from appreciation in the appreciation suitability indicator with employee expectations and needs, the Equality level of the appreciation system with the indicator of How far the appreciation level fulfills the equality feeling from the organizational viewpoint, and the Appreciation time range dimension in the indicator. How long is the appreciation given compared with work activities. While the largest percentage in the less agree criteria is in the Individual criteria and measurement dimension which provided appreciation in the appreciation suitability level with job length.

\section{Motivation Variable Descriptive Discussion}

From the descriptive analysis an average total score of the Motivation variable as large as $\mathbf{2 6 9}$ is obtained located in the scale range with the Very high criteria, which means that respondents already consider that Every employee has a very high work spirit in the frame of improving Employee Individual Performance and the Personnel and Training Board of Karawang Regency.

From the frequency tabulation that the respondent statement to the Motivation variable with the largest percentage in the strongly agree criteria is in the number 52 statement observed from the Satisfaction dimension in the Value attainment indicator. While the largest percentage in the less agree criteria is in the Satisfaction dimension in the Need fulfillment indicator.

\section{Performance Variable Descriptive Discussion}

From the descriptive analysis an average total score of the Performance variable as large as $\mathbf{2 6 5}$ is obtained located in the scale range with the Very high criteria, which means that respondents already consider that employee work results are already corresponding with the determined target by the Personnel and Training Board of Karawang Regency.

From the frequency tabulation that the respondent statement to the Performance variable with the largest percentage in the strongly agree criteria is in the Need for supervision dimension in the indicators of Service officer responsibility and Service officer politeness. While the largest percentage in the less agree criteria is in the Need for supervision dimension in the Service officer discipline indicator. 


\section{VERIFIED DISCUSSION}

The verified analysis can be seen in the following table:

Table 3 Verified Analysis Results

\begin{tabular}{|c|c|c|c|c|c|c|}
\hline Analysis & $\begin{array}{l}\text { Amoun } \\
\mathrm{t}\end{array}$ & $\begin{array}{l}\text { Sig } \\
\text { n. }\end{array}$ & $\begin{array}{c}\text { Meanin } \\
\mathrm{g}\end{array}$ & $\begin{array}{l}\text { t/f } \\
\text { count }\end{array}$ & $\begin{array}{c}\text { Meanin } \\
\mathrm{g}\end{array}$ & Conclusion \\
\hline Correlation $\mathrm{X}_{1}-\mathrm{X}_{2}$ & 3,29 & $\begin{array}{c}0,0 \\
12\end{array}$ & $<0,05$ & 2,760 & $>2,021$ & $\begin{array}{l}\text { Positive and } \\
\text { Significant at low } \\
\text { levels }\end{array}$ \\
\hline Influence of $\mathrm{X}_{1}$ to $\mathrm{Y}$ & $11 \%$ & $\begin{array}{c}0,0 \\
19 \\
\end{array}$ & $<0,05$ & 2,411 & $>2,021$ & $\begin{array}{l}\text { Positive and } \\
\text { Significant }\end{array}$ \\
\hline Influence of $\mathrm{X}_{2}$ to $\mathrm{Y}$ & $33,8 \%$ & $\begin{array}{c}0,0 \\
00\end{array}$ & $<0,05$ & 5,110 & $>2,021$ & $\begin{array}{l}\text { Positive and } \\
\text { Significant }\end{array}$ \\
\hline $\begin{array}{l}\text { Influence of } X_{1} \text { and } \\
X_{2} \text { to } Y\end{array}$ & $44.8 \%$ & $\begin{array}{c}0,0 \\
00\end{array}$ & $<0.05$ & 22.436 & $>3.16$ & $\begin{array}{l}\text { Positive and } \\
\text { Significant }\end{array}$ \\
\hline Influence of $X_{1}$ to $Z$ & $14.7 \%$ & $\begin{array}{c}0,0 \\
03\end{array}$ & $<0.05$ & 3.132 & $>2.021$ & $\begin{array}{l}\text { Positive and } \\
\text { Significant }\end{array}$ \\
\hline Influence of $X_{2}$ to $Z$ & $41 \%$ & $\begin{array}{c}0,0 \\
00\end{array}$ & $<0.05$ & 6.236 & $>2.021$ & $\begin{array}{l}\text { Positive and } \\
\text { Significant }\end{array}$ \\
\hline $\begin{array}{l}\text { Influence of } X_{1} \text { and } \\
X_{2} \text { to } Z\end{array}$ & $55.7 \%$ & $\begin{array}{c}0,0 \\
00\end{array}$ & $<0.05$ & 34.500 & $>3.16$ & $\begin{array}{l}\text { Positive and } \\
\text { Significant }\end{array}$ \\
\hline Influence of $\mathrm{Y}$ to $\mathrm{Z}$ & $66.4 \%$ & $\begin{array}{c}0,0 \\
00\end{array}$ & $<0.05$ & 15.941 & $>2.021$ & $\begin{array}{l}\text { Positive and } \\
\text { Significant }\end{array}$ \\
\hline $\begin{array}{l}\text { Influence of } X_{1} \\
\text { through } Y \text { to } Z\end{array}$ & $29.8 \%$ & $\begin{array}{l}0,0 \\
38 \\
\end{array}$ & $<0.05$ & $>2.122$ & 2.021 & $\begin{array}{l}\text { Positive and } \\
\text { Significant }\end{array}$ \\
\hline \multirow[t]{2}{*}{$\begin{array}{l}\text { Influence of } X_{2} \\
\text { through } Y \text { to } Z\end{array}$} & $59.3 \%$ & $\begin{array}{c}0,0 \\
03 \\
\end{array}$ & $<0.05$ & $>3.110$ & 2.021 & $\begin{array}{l}\text { Positive and } \\
\text { Significant }\end{array}$ \\
\hline & $89.1 \%$ & $\begin{array}{c}0,0 \\
00\end{array}$ & $<0.05$ & $\begin{array}{c}>213.5 \\
48\end{array}$ & 2.78 & $\begin{array}{l}\text { Positive and } \\
\text { Significant }\end{array}$ \\
\hline
\end{tabular}

Source: Processed based on source for research needs

Therefore the influence of Competence $\left(\mathrm{X}_{1}\right)$ and Compensation $\left(\mathrm{X}_{2}\right)$ to Performance $(\mathrm{Z})$ Through Motivation $(\mathrm{Y})$ is as large as 89.1\% larger than the influence of Competence $\left(\mathrm{X}_{1}\right)$ and Compensation $\left(\mathrm{X}_{2}\right)$ to Performance $(\mathrm{Z})$ as large as $\mathbf{5 5 . 7 \%}$. So Motivation (Y) has a strong and significant influence for mediating Competence $\left(\mathrm{X}_{1}\right)$ and Compensation $\left(\mathbf{X}_{2}\right)$ to Performance $(\mathrm{Z})$.

\section{CONCLUSION AND SUGGESTIONS Conclusion}

1. Employee competence has a very good criteria, meaning that Employee Competence is already corresponding with the primary tasks and functions of each Position. Yet there are still indicators which are poor that are technical/professional/managerial expertise and self-control.

2. Compensation has a good criteria, which means that the Compensation provided by the Personnel and Training Board of Karawang Regency is already corresponding with Employee expectations and corresponding with the ability of the Personnel and Training Board of Karawang Regency. Yet there is still an indicator which is poor which the appreciation suitability level with job length is. 
THE EFFECT OF COMPETENCE AND COMPENSATION TO MOTIVATION OF EMPLOYEES AND ITS IMPACT ON EMPLOYEE PERFORMANCE IN THE PERSONNEL AND TRAINING BOARD OF KARAWANG REGENCY

3. Work Motivation has a very high criteria, meaning every employee has a high work spirit in the frame of improving Employee Individual Performance and the Personnel and Training Board of Karawang Regency Performance. Yet there is still a low indicator which is the Need fulfillment.

4. Employee Performance has a very high criteria, meaning employee work results are already corresponding with what is determined by the Personnel and Training Board of Karawang Regency. Yet there is still a low indicator which is Service officer discipline.

5. Competence with Compensation has a positive and significant correlation in the low correlation level, this shows that if Employee Competence increases, the Compensation provided also increases, also the contrary. But the relation level is low, which means there are still other factors outside Competence and Compensation which have stronger correlations than those two factors.

6. The influence of Competence to Work Motivation is as large as $11 \%$. Competence has a positive influence to Work Motivation meaning that the Competence variable significantly influences Work Motivation, therefore the higher the employee competence, the Employee Work Motivation will also be higher.

The influence of Compensation to Work Motivation is as large as 33\%. Compensation has a positive influence to Work Motivation meaning that the Compensation variable significantly influences Work Motivation, therefore the higher the good compensation provided, the Employee Work Motivation will also be higher.

7. The influence of Competence and Compensation simultaneously to Work Motivation is as large as $44.8 \%$. Competence and Compensation have positive influences to Work Motivation meaning the Competence and Compensation variables significantly influence Work Motivation, therefore the higher the Competence and Compensation, the Employee Work Motivation will also be higher. But there are still other factors outside of Competence and Compensation which are not investigated which influence Work Motivation as large as $55.2 \%$.

8. The influence of Competence to Employee Performance is as large as $14.7 \%$. Competence has a positive influence to Employee Performance meaning that the Competence variable significantly influences Employee Performance, therefore the higher the employee competence, the Employee Performance will also be higher.

The influence of Compensation to Employee Performance is as large as 41\%. Compensation has a positive influence to Employee Performance meaning that the Compensation variable significantly influences Employee Performance, therefore the higher the good compensation provided, the Employee Performance will also be higher.

9. The influence of Competence and Compensation simultaneously to Employee Performance is as large as 55.7\%. Competence and Compensation have positive influences to Employee Performance meaning the Competence and Compensation variables significantly influence Employee Performance, therefore the higher the Competence and Compensation, the Employee Performance will also be higher. But there are still other factors outside of Competence and Compensation which are not investigated which influence Employee Performance as large as $44.3 \%$. 
10. The influence of Work Motivation to Employee Performance is as large as $66.4 \%$. Work Motivation has a positive influence to Employee Performance meaning that the Work Motivation variable significantly influences Employee Performance, therefore the higher the Employee Work Motivation, the Employee Performance will also be higher.

11. The influence of Competence through Work Motivation to Employee Performance is as large as $29.8 \%$. Competence through Work Motivation has a positive influence to Employee Performance meaning that the Competence through Work Motivation variable significantly influences Employee Performance, therefore the higher the Competence through Work Motivation, the Employee Performance will also be higher.

The influence of Compensation through Work Motivation to Employee Performance is as large as $59.3 \%$. Compensation through Work Motivation has a positive influence to Employee Performance meaning that the Compensation through Work Motivation variable significantly influences Employee Performance, therefore the higher the Compensation through Work Motivation, the Employee Performance will also be higher.

12. The influence of Competence and Compensation simultaneously through Motivation to Employee Performance is as large as 89.1\%. Competence and Compensation through Motivation have positive influences to Employee Performance meaning the Competence and Compensation through Motivation variables significantly influence Employee Performance, therefore the higher the Competence and Compensation through Motivation, the Employee Performance will also be higher. But there are still other factors outside of Competence and Compensation through Motivation which are not investigated which influence Employee Performance as large as $10.9 \%$.

\section{Suggestions}

1. Good Employee Competence needs to be maintained, moreover needs to be improved and optimized back to be able to improve performance and in the frame of reaching good governance. The low indicators of technical/professional/managerial expertise and self-control needs to be improved by ways of:

a. Developing Employee technical, professional, managerial competence by implementing training need analysis which consist of Organizationbased need analysis, Job competence-based need analysis, and Individual competence-based need analysis.

b. Develop individual self-control by developing a performance system management which is objective and able to avoid like and dislike situations, and create an optimal career management system.

2. A good Compensation needs to be maintained, moreover needs to be improved. The low indicator of the appreciation suitability level with work length needs to be improved by arranging the job grading and salary structure which covers non-analytical methods in arranging the remuneration scale and position evaluation, analytical methods and points rating in arranging the remuneration scale and position evaluation, salary grading based on measured compensable factors, a remuneration scale based on the 3P (Pay for Person, Position, and Performance) principle. 
THE EFFECT OF COMPETENCE AND COMPENSATION TO MOTIVATION OF EMPLOYEES AND ITS IMPACT ON EMPLOYEE PERFORMANCE IN THE PERSONNEL AND TRAINING BOARD OF KARAWANG REGENCY

3. A good Compensation needs to be maintained, moreover needs to be improved. The low indicator

of the Need fulfillment has to be improved by arranging talent management and strategy, measuring competence with an assessment center, measuring performance appraisal based on KPI, measuring a competence based HR management system.

4. The already high Employee Performance needs to be maintained, moreover needs to be improved more. The low indicator of Service Officer Discipline needs to be improved by implementing HR and OD (Organizational Development) auditing to be able to produce an optimal auditing process, and provide a positive impact for performance improvement of the Human Resources department service and Organization development.

5. Competence with Compensation has a positive and significant correlation with a low level of correlation. For improving the correlation between Competence and Compensation in the frame of improving Performance, the Compensation provided should be Competence based, able to be implemented by arranging a competence-based HR management system, arranging a KPI based performance appraisal in the frame of arranging a reward and punishment based policy.

6. From the influence test result, it is obtained an indirect influence of Competence and Compensation to Employee Performance through Work Motivation as high as $89.1 \%$ larger than the direct influence of Competence and Compensation to Employee Performance through Motivation as large as $55.7 \%$ so Work Motivation becomes a variable that mediates between Competence and Compensation to Employee Performance. For improving Employee Performance, it should be applied all key functions in the Human Resource management science beginning with the recruitment function, training and development, career management, performance assessment up to the remuneration strategy function to be able to improve Employee Work Motivation which in the end will impact Employee Performance improvement.

7. The influence of other variables that are not investigated outside of Competence and Compensation through Work Motivation is as large as $10.9 \%$. It is expected to be from other variables such as the leadership variable, organization culture, work environment, organization commitment, work stress, and others, so further research of the other variables needs to be implemented for obtaining information that is comprehensive in the frame of Employee Performance improvement.

\section{References}

Act of the Republic of Indonesia Number 5 Year 2014 About National Civil Apertures.

Accountability Report of Government Institution Personnel and Training Board Karawang Regency Year 2016.

Kadarisman, M. (2014). Manajemen Kompensasi. Edisi 1 Cetakan ke-2. Jakarta: Rajawali Pers.

Robbins, S. P. (2012). Management. New Jersey: Pearson Education, Inc. 
Sudarmanto. (2015). Kinerja dan Pengembangan Kompetensi SDM. Cetakan ke-3. Yogyakarta: Pustaka Pelajar, 2015.

Sugiyono. (2014). Metode Penelitian Kuantitatif dan Kualitatif dan R\&D. Cetakan ke-21. Bandung: Alfabeta.

Wibowo. (2010). Manajemen Kinerja. Cetakan ke-3. Jakarta: Rajawali Pers.

Winardi, J. (2011). Motivasi dan Pemotivasian dalam Manajemen. Edisi 1 Cetakan ke-6. Jakarta: Rajawali Pers.

Arumwanti, W. (2012). Pengaruh Kompetensi dan Kompensasi terhadap Motivasi Kerja Karyawan Hotel di Kabupaten Karo Sumatera Utara. Dosen Akademi Pariwisata Medan. Jurnal Riset Akuntansi dan Bisnis Vol 12 No. 2/ September 2012.

Bagja, I. M. S. A., Cipta, W., \& Wayan, I. (2016). Pengaruh Kompetensi dan Kompensasi Financial terhadap Kinerja Karyawan. e-Journal Bisma Universitas Pendidikan Ganesha Singaraja Jurusan Manajemen, 4.

Daulay, Z. R. (2014). Pengaruh Kompetensi dan Etika Kerja terhadap Motivasi Kerja dan Dampaknya terhadap Kinerja Pegawai Negeri Sipil Kecamatan di Kabupaten Serdang Bedagai. [Thesis]. Jakarta: Universitas Terbuka.

Head of National Employment Regulation Number 7 Year 2013 About the Guide of Government Employee Competence Standard Management.

Putra, H. E., Yunus. M., \& Mahdani. (2015). Pengaruh Kompetensi, Komunikasi dan Kesejahteraan terhadap Motivasi dan implikasinya pada Kinerja Karyawan Kantor Pusat Operasional PT. Bank Aceh. Jurnal Manajemen Pascasarjana Universitas Syiah Kuala, 4(3), 72- 81.

Ratnasari, S. L. (2016). Pengaruh Kompetensi dan Kompensasi terhadap Kinerja Karyawan Departemen Quality Assurance PT. PEB Batam. Proceeding the National Seminar of Economics and Business \& Call For Paper Faculty of Economics and Business Sidoarjo Muhammadiyah University 2016.

Republic of Indonesia Government Regulation Number 11 Year 2017 About Government Employee Management.

Sarifuddin. (2016). Pengaruh Kompetensi terhadap Kinerja Pegawai dengan Motivasi Kerja sebagai Variabel Intervenning pada Badan pusat Statistik Provinsi Sulawesi Barat. [Thesis]. Jakarta: Universitas Terbuka.

Suryoko, S., \& Mudayana, F. I. (2016). Pengaruh Kompetensi, Kompensasi, dan Lingkungan Kerja terhadap Kinerja Karyawan melalui Motivasi Kerja Sebagai Variabel Intervening (Studi Kasus pada Karyawan Bagian Produksi PT. Sai Apparel Industries Semarang). Business Administration Science Journal, 5(1).

Cara Uji Analisis Jalur (Path Analysis) dengan SPSS Lengkap in www.spssindonesia.com. Accessed on July 2017. 
THE EFFECT OF COMPETENCE AND COMPENSATION TO MOTIVATION OF

EMPLOYEES AND ITS IMPACT ON EMPLOYEE PERFORMANCE IN THE PERSONNEL

AND TRAINING BOARD OF KARAWANG REGENCY

Makna Koefisien Determinasi (R Square) dalam Analisis Regresi Linear in www.spssindonesia.com. Accessed on July 2017.

Modul Pelatihan SPSS, Aplikasi pada Penelitian Sosial in https://www.researchgate.net/publication/297713810. Accessed on July 2017.

Modul HR Management Online MasterClass oleh Yodhia Antariksa, Msc in HR Management in https://edubisnis.net. Accessed on July 2017.

SPSS Korelasi dan Regresi dalam https://samianstats.files.wordpress.com. Accessed on July 2017.

Tutorial Transformasi Data Ordinal ke Data Interval Menggunakan Microsoft Add-Ins. Stat 97.xla pada Microsoft Excel in https://labict.budiluhur.ac.id. Accessed on July 2017.

Uji Asumsi Klasik dan Uji Regresi Linear Berganda in https://dadukembar.blogspot.co.id/2015/02/uji-asumsi-klasik-dan-ujiregresi.html. Accessed on July 2017. 